\title{
The relationship between the authentic leadership of nurses and structural empowerment: a systematic review
}

\author{
A relação entre a liderança autêntica dos enfermeiros e o \\ empoderamento estrutural: revisão sistemática \\ La relación entre el liderazgo auténtico de los enfermeros y el \\ empoderamiento estructural: una revisión sistemática
}

How to cite this article:

Valle RBLR, Balsanelli AP, Taminato M, Saconato H, Gasparino R. The relationship between the authentic leadership of nurses and structural empowerment: a systematic review. Rev Esc Enferm USP. 2021;55:e03667. doi: https://doi.org/10.1590/S1980-220X2019029003667

Rebeca Beatriz Lucena Ribeiro do Valle ${ }^{1}$

(D) Alexandre Pazetto Balsanelli ${ }^{1}$
(i) Mônica Taminato ${ }^{1}$
(D) Humberto Saconato ${ }^{2}$
(D) Renata Gasparino ${ }^{3}$

${ }^{1}$ Universidade Federal de São Paulo, Escola Paulista de Enfermagem, São Paulo, SP, Brazil

${ }^{2}$ Universidade Federal de São Paulo, Escola Paulista de Medicina, São Paulo, SP, Brazil.

${ }^{3}$ Universidade Estadual de Campinas, Faculdade de Enfermagem, Campinas, SP, Brazil.

\begin{abstract}
Objective: To verify the relationship between authentic leadership of nurses and structural empowerment. Method: This is a systematic review carried out at the Virtual Health Library on the Journal Portal of the Coordination for the Improvement of Higher Education Personnel, Online System for the Search and Analysis of Medical Literature, Scientific Electronic Library Online and Science Direct/Embase, and consulted until April 2019. Studies with nurses, evidencing the relationship between authentic leadership and structural empowerment, published between 2012 and 2018 in Brazilian Portuguese, English or Spanish were included. Results: Five studies were included, with variables other than structural empowerment: job satisfaction, burnout, bulling, mental health, performance, social capital, working environment, nurse retention, and quality of care. Authentic leadership showed a positive relationship with structural empowerment, improving engagement and job satisfaction, reducing burnout and increasing quality of care. Conclusion: Health institutions, in addition to Canada, where researchers on this topic are located, can invest in authentic leadership to improve structural empowerment by providing greater commitment from nurses, increased job satisfaction and quality of care provided.
\end{abstract}

\section{DESCRIPTORS}

Nursing; Leadership; Working Environment; Power Psychological; Review.
Corresponding author:

Rebeca Beatriz Lucena Ribeiro do Valle

Universidade Federal de São Paulo,

Escola Paulista de Enfermagem

Rua Napoleão de Barros, 754, Vila Clementino

CEP 04024-002 - São Paulo, SP, Brazil

rebeca.lucena@uol.com.br 


\section{INTRODUCTION}

Nurses' leadership plays a fundamental role in generating better results for health organizations and, especially for patients. The leader's ability to delegate tasks and assign responsibilities to the nursing team has a direct impact on the workplace, interfering with the relationship among individuals, exchange of knowledge and skills among members of the same team ${ }^{(1-3)}$.

The concept and exercise of authentic leadership has emerged in the last 15 years based on building authentic relationships and organizations with self-conscious leaders who seek their constant development and the exercise of more transparent and ethical relationships. This leadership model exercised by nurses is based on the authenticity stimulated by the leaders themselves, which can provide relationships supported by trust, integrity and high moral standards, making leaders to be true to themselves ${ }^{(4-7)}$.

The exercise of authentic leadership by nurses and their staff promotes positive impacts on health institutions. Authentic leaders are able to contribute to the appreciation of individuals and thus generate a better performance of the entire team in search of better results ${ }^{(5)}$.

Structural empowerment refers to policies, practices and organizational structures that provide leaders with a greater degree of knowledge to make decisions and exercise influence. Structural empowerment is described as a socio-structural phenomenon that focuses on a set of organizational policies and practices initiated by management. It aims to address conditions that promote the development of power and support decision making through the organizational hierarchy ${ }^{(8)}$.

Structural empowerment in the workplace, as well as access to opportunities have a direct impact on the attitudes and behaviors of nursing professionals. For nurses, access to resources, information and institutional support facilitates their growth and development, ensuring the necessary engagement to carry out their tasks, contributing to professionals becoming more flexible and creative ${ }^{(8)}$.

Leadership is directly related to structural empowerment that reflects leaders' attitudes in creating conditions in a working environment that favor the development of power, delegation of decision-making, authority and responsibility by the organization's hierarchy ${ }^{(9)}$.

Working environment conditions can encourage or discourage the nursing team's work, since they directly affect the personal issues of those submitted to them. The working environment where structural empowerment is present fosters important organizational results, such as reduced burnout, increased employee performance, in addition to respect and cooperation among health team members, which directly impacts customer satisfaction and patient's safety ${ }^{(8-10)}$.

The way in which leadership is exercised by nurses has a strong relationship with satisfaction in the team's work and with health outcomes achieved by institutions. It is questioned, in this study, how authentic leadership is related to structural empowerment to create strategies that aim to increase positive results in health care.

Therefore, this study aims to verify the relationship between authentic leadership of nurses and structural empowerment.

\section{METHOD}

\section{StUdDY DESIGN}

This is a systematic literature review that followed the steps proposed by Cochrane Collaboration ${ }^{(11)}$. PICO strategy ${ }^{(12)}$ was used. P stands for nurses, I stands for exercise of authentic leadership, $\mathrm{C}$ stands for no comparison, and $\mathrm{O}$ stands for relationship with structural empowerment.

The Virtual Health Library (VHL), Portal of Journals of the Coordination for the Improvement of Higher Education Personnel (CAPES - Coordenação de Aperfeiçoamento de Pessoal de Ensino Superior), Online System for the Search and Analysis of Medical Literature (MEDLINE/PubMed), Scientific Electronic Library Online (SciELO) and Science Direct/Embase were consulted until April 2019. The descriptors used in the search strategy were identified based on PubMed and replicated to the other libraries and databases as shown in Chart 1.

Chart 1 - Research strategies applied by database.

\begin{tabular}{|c|c|c|c|c|c|c|}
\hline Database & \multicolumn{6}{|c|}{ Research formula } \\
\hline BVS & $\begin{array}{c}\text { authentic } \\
\text { leadership AND } \\
\text { nurses AND } \\
\text { empowerment } \\
\text { AND (collection: } \\
\text { ("06-national/ } \\
\text { BR" OR } \\
\text { "05-specialized") } \\
\text { OR db: ("LILACS" } \\
\text { OR “MEDLINE")) }\end{array}$ & $\begin{array}{c}\text { authentic } \\
\text { leadership AND } \\
\text { nurses AND } \\
\text { empowerment } \\
\text { structural AND } \\
\text { (collection: } \\
\text { ("06-national/ } \\
\text { BR" OR } \\
\text { "05-specialized") } \\
\text { OR db: (“LILACS" } \\
\text { OR "MEDLINE")) }\end{array}$ & $\begin{array}{l}\text { leadership AND } \\
\text { health facility } \\
\text { environment AND } \\
\text { empowerment } \\
\text { AND (collection: } \\
\text { ("06-national/ } \\
\text { BR" OR } \\
\text { "05-specialized") } \\
\text { OR db: ("LILACS" } \\
\text { OR "MEDLINE")) }\end{array}$ & $\begin{array}{c}\text { leadership } \\
\text { AND working } \\
\text { environment AND } \\
\text { empowerment } \\
\text { AND (collection: } \\
\text { ("06-national/ } \\
\text { BR" OR } \\
\text { "05-specialized") } \\
\text { OR db: ("LILACS" } \\
\text { OR "MEDLINE")) }\end{array}$ & $\begin{array}{c}\text { leadership AND } \\
\text { nurses AND health } \\
\text { facility environment } \\
\text { AND empowerment } \\
\text { AND (collection: } \\
\text { ("O6-national/BR" OR } \\
\text { "05-specialized") OR } \\
\text { db: (“LILACS" OR } \\
\text { "MEDLINE")) }\end{array}$ & $\begin{array}{c}\text { leadership AND } \\
\text { nurses AND working } \\
\text { environment AND } \\
\text { empowerment } \\
\text { AND (collection: } \\
\text { ("06-national/BR" } \\
\text { OR "05-specialized") } \\
\text { OR db: ("LILACS" } \\
\text { OR "MEDLINE")) }\end{array}$ \\
\hline
\end{tabular}

continuing... 


\begin{tabular}{|c|c|c|c|c|c|c|}
\hline $\begin{array}{l}\text { MEDLINE } \\
\text { /PubMed }\end{array}$ & $\begin{array}{l}\text { authentic [All } \\
\text { Fields] AND } \\
\text { ("leadership" } \\
\text { [MeSH Terms] } \\
\text { OR "leadership" } \\
\text { [All Fields]) } \\
\text { AND ("nurses" } \\
\text { [MeSH Terms] } \\
\text { OR "nurses" [All } \\
\text { Fields]) AND } \\
\text { ("empowerment" } \\
\text { [MeSH Terms] OR } \\
\text { "empowerment" } \\
\text { [All Fields]) }\end{array}$ & $\begin{array}{l}\text { authentic [All } \\
\text { Fields] AND } \\
\text { ("leadership" } \\
\text { [MeSH Terms] } \\
\text { OR "leadership" } \\
\text { [All Fields]) } \\
\text { AND ("nurses" } \\
\text { [MeSH Terms] } \\
\text { OR "nurses" [All } \\
\text { Fields]) AND } \\
\text { ("empowerment" } \\
\text { [MeSH Terms] OR } \\
\text { "empowerment" } \\
\text { [All Fields]) AND } \\
\text { structural [All } \\
\text { Fields] }\end{array}$ & $\begin{array}{c}\text { ("leadership" } \\
\text { [MeSH Terms] } \\
\text { OR "leadership" } \\
\text { [All Fields]) AND } \\
\text { ("health facility } \\
\text { environment" } \\
\text { [MeSH Terms] } \\
\text { OR (“health" } \\
\text { [All Fields] AND } \\
\text { "facility" [All } \\
\text { Fields] AND } \\
\text { "environment" } \\
\text { [All Fields]) OR } \\
\text { "health facility } \\
\text { environment" } \\
\text { [All Fields]) AND } \\
\text { ("empowerment" } \\
\text { [MeSH Terms] OR } \\
\text { "empowerment" } \\
\text { [All Fields]) }\end{array}$ & $\begin{array}{c}\text { ("leadership" } \\
\text { [MeSH Terms] } \\
\text { OR "leadership" } \\
\text { [All Fields]) AND } \\
\text { ("work" [MeSH } \\
\text { Terms] OR "work" } \\
\text { [All Fields] OR } \\
\text { "working" [All } \\
\text { Fields]) AND } \\
\text { ("environment" } \\
\text { [MeSH Terms] OR } \\
\text { "environment" } \\
\text { [All Fields]) AND } \\
\text { ("empowerment" } \\
\text { [MeSH Terms] OR } \\
\text { "empowerment" } \\
\text { [All Fields]) }\end{array}$ & $\begin{array}{l}\text { ("leadership" } \\
\text { [MeSH Terms] OR } \\
\text { "leadership" [All } \\
\text { Fields]) AND ("nurses" } \\
\text { [MeSH Terms] OR } \\
\text { "nurses" [All Fields]) } \\
\text { AND ("health facility } \\
\text { environment" [MeSH } \\
\text { Terms] OR ("health" } \\
\text { [All Fields] AND } \\
\text { "facility" [All Fields] } \\
\text { AND “environment" } \\
\text { [All Fields]) OR "health } \\
\text { facility environment" } \\
\text { [All Fields]) AND } \\
\text { ("empowerment" } \\
\text { [MeSH Terms] OR } \\
\text { "empowerment" [All } \\
\text { Fields]) }\end{array}$ & $\begin{array}{c}\text { ("leadership" } \\
\text { [MeSH Terms] } \\
\text { OR "leadership" } \\
\text { [All Fields]) AND } \\
\text { ("nurses" [MeSH } \\
\text { Terms] OR "nurses" } \\
\text { [All Fields]) AND } \\
\text { ("work" [MeSH } \\
\text { Terms] OR "work" } \\
\text { [All Fields] OR } \\
\text { "working" [All } \\
\text { Fields]) AND } \\
\text { ("environment" } \\
\text { [MeSH Terms] OR } \\
\text { "environment" } \\
\text { [All Fields]) AND } \\
\text { ("empowerment" } \\
\text { [MeSH Terms] OR } \\
\text { "empowerment" [All } \\
\text { Fields]) }\end{array}$ \\
\hline $\begin{array}{l}\text { Science } \\
\text { Direct / } \\
\text { Embase }\end{array}$ & $\begin{array}{l}\text { "authentic } \\
\text { leadership" and } \\
\text { "nurses" and } \\
\text { "empowerment" }\end{array}$ & $\begin{array}{l}\text { "authentic } \\
\text { leadership" and } \\
\text { "nurses" and } \\
\text { "empowerment } \\
\text { structural" }\end{array}$ & $\begin{array}{l}\text { "leadership" and } \\
\text { "Health Facility } \\
\text { Environment" and } \\
\text { "empowerment" }\end{array}$ & $\begin{array}{l}\text { "leadership" } \\
\text { and "Working } \\
\text { Environment" and } \\
\text { "empowerment" }\end{array}$ & $\begin{array}{l}\text { "leadership" and } \\
\text { "nurses" and "Health } \\
\text { Facility Environment" } \\
\text { and "empowerment" }\end{array}$ & $\begin{array}{l}\text { "leadership" } \\
\text { and "nurses" } \\
\text { and "Working } \\
\text { Environment" and } \\
\text { "empowerment" }\end{array}$ \\
\hline SciELO & $\begin{array}{c}\text { authentic } \\
\text { leadership [All } \\
\text { indexes] and } \\
\text { nurses [All } \\
\text { indexes] and } \\
\text { empowerment [All } \\
\text { indexes] }\end{array}$ & $\begin{array}{c}\text { authentic } \\
\text { leadership [All } \\
\text { indexes] and } \\
\text { nurses [All } \\
\text { indexes] and } \\
\text { empowerment } \\
\text { structural [All } \\
\text { indexes] }\end{array}$ & $\begin{array}{l}\text { leadership [All } \\
\text { indexes] and } \\
\text { Health Facility } \\
\text { Environment [All } \\
\text { indexes] and } \\
\text { empowerment [All } \\
\text { indexes] }\end{array}$ & $\begin{array}{c}\text { leadership } \\
\text { [All indexes] } \\
\text { and Working } \\
\text { Environment [All } \\
\text { indexes] and } \\
\text { empowerment [All } \\
\text { indexes] }\end{array}$ & $\begin{array}{l}\text { leadership [All indexes] } \\
\text { and nurses [All } \\
\text { indexes] and Health } \\
\text { Facility Environment } \\
\text { [All indexes] and } \\
\text { empowerment [All } \\
\text { indexes] }\end{array}$ & $\begin{array}{l}\text { leadership [All } \\
\text { indexes] and } \\
\text { nurses [All indexes] } \\
\text { and Working } \\
\text { Environment [All } \\
\text { indexes] and } \\
\text { empowerment [All } \\
\text { indexes] }\end{array}$ \\
\hline $\begin{array}{l}\text { CAPES/ } \\
\text { MEC }\end{array}$ & $\begin{array}{l}\text { "authentic } \\
\text { leadership" and } \\
\text { "nurses" and } \\
\text { "empowerment" }\end{array}$ & $\begin{array}{l}\text { "authentic } \\
\text { leadership" and } \\
\text { "nurses" and } \\
\text { "empowerment } \\
\text { structural" }\end{array}$ & $\begin{array}{l}\text { "leadership" and } \\
\text { "Health Facility } \\
\text { Environment" and } \\
\text { "empowerment" }\end{array}$ & $\begin{array}{l}\text { "leadership" } \\
\text { and "Working } \\
\text { Environment" and } \\
\text { "empowerment" }\end{array}$ & $\begin{array}{l}\text { "leadership" and } \\
\text { "nurses" and "Health } \\
\text { Facility Environment" } \\
\text { and "empowerment" }\end{array}$ & $\begin{array}{l}\text { "leadership" } \\
\text { and "nurses" } \\
\text { and "Working } \\
\text { Environment" and } \\
\text { "empowerment" }\end{array}$ \\
\hline
\end{tabular}

\section{SELECTION CRITERIA}

Original studies, with nurses as participants, without restriction of time of training and performance in the field, which evidenced the relationship of authentic leadership and structural empowerment, regardless the period of publication, available in Brazilian Portuguese, English or Spanish were included.

Research that did not have outcomes related to authentic leadership exercised by nurses and structural empowerment or that was associated with other types of empowerment were excluded.

The selected abstracts were read by two reviewers using the inclusion criteria. Later, the selected articles were read in full. In cases of doubt, a third reviewer was asked for clarification.

\section{Data collection}

The following variables were included in the instrument for data extraction: title; authors; year and country of publication; study population (N); average age of participants and instrument used to assess authentic leadership; structural empowerment; methodological quality assessment according to the recommendations of Critical Appraisal of CrossSectional Study (Survey) at the Center for Evidence-Based Management (CEBMa) ${ }^{(13)}$ and the Methodology Checklist 3: Cohort Studies of the Scottish Intercollegiate Guidelines Network (SIGN) ${ }^{(14)}$. They aim to carry out a careful and systematic assessment of the research evidence to judge its reliability, value and relevance.

\section{RESULTS}

In total, 2,018 articles were found, of which 1,925 were excluded by titles and abstracts. A search at VHL resulted in 83 studies, at PubMed, 154, at Embase, 1,723, at LILACS, 0 , at SciELO, 0, and at CAPES Portal of Journals, 58. In the first search, carried out by two reviewers, 93 studies were preselected from reading titles and abstracts. Of these studies, 68 were excluded because they were in duplicate. Of the 25 
remaining studies selected, 20 were excluded because they did not meet the inclusion criteria. Among the excluded, ten did not address authentic leadership; two studies did not directly address structural empowerment; one addressed psychological empowerment; six dealt with secondary analysis and application of hypothesis; a study was published in Korean. All included studies were written in English.
In this review, five studies were included, after analyzing the content to summarize the results. A meta-analysis was not possible due to the heterogeneity of the study designs.

Figure 1 presents a search and selection flowchart with the distribution of all articles found following the inclusion and exclusion criteria according to the Preferred Reporting Items for Systematic Reviews and Meta-Analyzes (PRISMA) ${ }^{(15)}$.

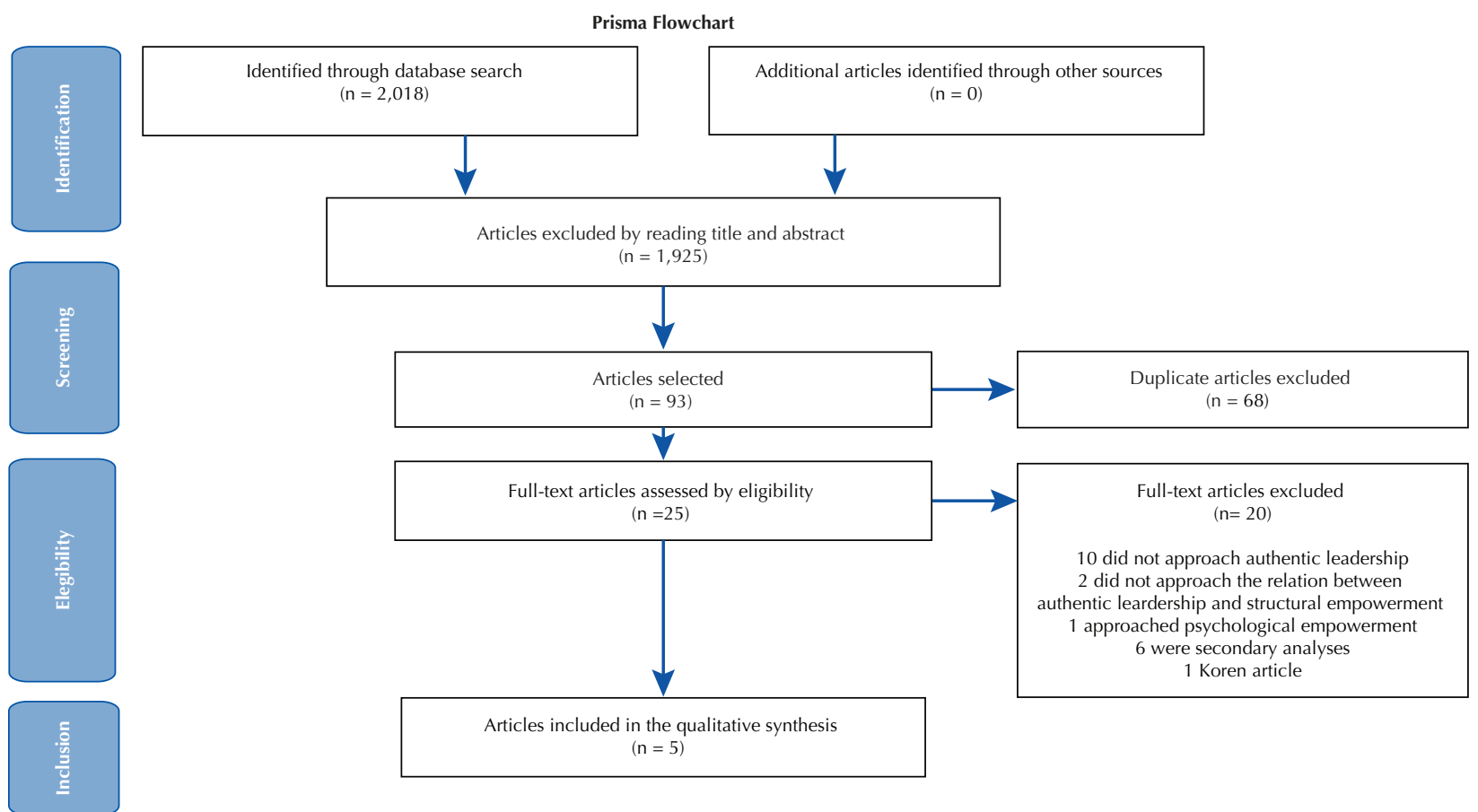

Figure 1 - Flowchart for selection of studies identification - PRISMA ${ }^{(15)}$.

All studies were published between 2012 and 2018, 80\% of the researched samples were from women with an average age of 36 years and the country of origin was Canada (5), which can be identified in Chart 2. There is a repetition of authors in the included studies because authentic leadership is a recent topic and is widely discussed in this group of researchers.

Chart 2 - Synthesis of the characteristics of the included studies.

\begin{tabular}{|c|c|c|}
\hline Author & Objectives & Sample (n) \\
\hline $\begin{array}{l}\text { Laschinger HKS; Wong CA; Grau AL. } \\
\text { Canada, 2013 }\end{array}$ & $\begin{array}{l}\text { To delve into the effect of authentic leadership and structural } \\
\text { empowerment on emotional exhaustion and cynicism in newly } \\
\text { graduated and experienced intensive care nurses. }\end{array}$ & 616 \\
\hline $\begin{array}{l}\text { Wong CA; Laschinger HKS } \\
\text { Canada, } 2012^{(17)}\end{array}$ & $\begin{array}{l}\text { To test a model that relates the authentic leadership of managers } \\
\text { with nurses' perceptions on structural empowerment, performance } \\
\text { and job satisfaction. }\end{array}$ & 208 \\
\hline $\begin{array}{l}\text { Boamah AS; Read EA; Laschinger HKS } \\
\text { Canada, 2016 }\end{array}$ & $\begin{array}{l}\text { To test a hypothetical model that links the perceptions of new } \\
\text { graduated nurses about the authentic leadership behaviors of their } \\
\text { managers to structural empowerment, lack of employees and work- } \\
\text { life interference and subsequent wear and tear, job satisfaction and } \\
\text { quality of patient care. }\end{array}$ & 406 \\
\hline $\begin{array}{l}\text { Laschinger HKS; Fida R } \\
\text { Canada, 2015 }\end{array}$ & $\begin{array}{l}\text { To test a model that links authentic leadership, structural } \\
\text { empowerment and professional practice environments to support } \\
\text { nurses' perceptions of quality of patient care and job satisfaction. }\end{array}$ & 723 \\
\hline $\begin{array}{l}\text { Read EA, Laschinger HKS } \\
\text { Canada, } 2015^{(20)}\end{array}$ & $\begin{array}{l}\text { To delve into a theoretical model that tests the effects of authentic } \\
\text { leadership, structural empowerment and relational social capital } \\
\text { on the mental health and job satisfaction of recent graduates in the } \\
\text { first year of practice. }\end{array}$ & 191 \\
\hline
\end{tabular}


Among the five studies included in this review, other variables were also addressed in addition to structural empowerment such as job satisfaction, burnout, bullying, nurses' mental health, performance, social capital, working environment, nurse retention and quality of patient care. All studies used Conditions of Work Effectiveness II (CWEQ-II) to assess structural empowerment.

Chart 3 shows that the included studies were observational, being: four longitudinal ${ }^{(16-18,20)}$ (cohort) and one cross-sectional ${ }^{(19)}$. After assessing methodological quality, a study was assessed using the Critical Appraisal of CrossSectional Study (Survey) of CEBMa ${ }^{(13)}$, and filled $92 \%$ of the 12 items present in the instrument, which rated it as high quality. Of the four studies analyzed with the Methodology Checklist 3: Cohort studies of SIGN ${ }^{(14)}$, two studies filled $67 \%$ of items, one $72 \%$ and another $78 \%$. The studies that were below $70 \%{ }^{(18-19)}$ filled 12 out of 18 items and can be considered acceptable. The sample was compromised in both, as $52 \%{ }^{(17)}$ and $60 \%{ }^{(18)}$ of participants did not answer the second stage of the research.

Chart 3 - Synthesis of study results.

\begin{tabular}{|c|c|c|c|c|c|}
\hline \multirow[b]{2}{*}{ Author } & \multirow[b]{2}{*}{$\begin{array}{c}\text { Other } \\
\text { variables } \\
\text { addressed }\end{array}$} & \multirow[b]{2}{*}{ Study design } & \multirow[b]{2}{*}{ Outcomes } & \multicolumn{2}{|c|}{$\begin{array}{l}\text { Instruments used to assess } \\
\text { methodological quality }\end{array}$} \\
\hline & & & & $\begin{array}{c}\text { Critical } \\
\text { Appraisal of a } \\
\text { Cross-Sectional } \\
\text { study (Survey) } \\
(13)\end{array}$ & $\begin{array}{l}\text { Methodology } \\
\text { Checklist 3: } \\
\text { Cohort studies } \\
\text { of the Scottish } \\
\text { Intercollegiate } \\
\text { Guidelines } \\
\text { Network (SIGN) }\end{array}$ \\
\hline $\begin{array}{l}\text { Laschinger } \\
\text { HKS; Wong CA; } \\
\text { Grau AL }{ }^{(16)}\end{array}$ & Burnout & Longitudinal & $\begin{array}{l}\text { The authentic behavior of nursing leaders } \\
\text { was important for nurses, in which the } \\
\text { perception of structural empowerment } \\
\text { strengthened the working environment } \\
\text { ( } \beta=0.411, \mathrm{P}<0.001 \text { ) for experienced } \\
\text { nurses; } \beta=0.402, \mathrm{P}<0.001 \text { ) for recent } \\
\text { graduates, and contributed to lower } \\
\text { levels of emotional exhaustion ( } \beta=0.314 \text {, } \\
\mathrm{P}<0.001 \text { ) for experienced nurses; } \\
(\beta=0.164, \mathrm{P}=0.006 \text { ) for recent graduates). }\end{array}$ & --- & $67 \%$ \\
\hline $\begin{array}{l}\text { Wong CA; } \\
\text { Laschinger } \\
\text { HKS }^{(17)}\end{array}$ & $\begin{array}{l}\text { Performance } \\
\text { and job } \\
\text { satisfaction }\end{array}$ & Longitudinal & $\begin{array}{c}\text { Authentic leadership significantly } \\
\text { influenced nurses' structural } \\
\text { empowerment }(\beta=0.46, \mathrm{P}<0.01) \text {, which } \\
\text { had a direct effect on job satisfaction } \\
(\beta=0.41, \mathrm{P}<0.01) \text { and performance } \\
(\beta=0.17, \mathrm{P}<0.01) \text {. }\end{array}$ & --- & $67 \%$ \\
\hline $\begin{array}{l}\text { Boamah AS; } \\
\text { Read EA; } \\
\text { Laschinger } \\
\text { HKS }^{(18)}\end{array}$ & $\begin{array}{l}\text { Burnout, job } \\
\text { satisfaction } \\
\text { and quality of } \\
\text { patient care }\end{array}$ & Longitudinal & $\begin{array}{l}\text { Authentic leadership had a positive effect } \\
\text { on structural empowerment }(\beta=0.63 \text {, } \\
\mathrm{P}<0.001) \text {, which can have a direct } \\
\text { influence on reducing the emergence of } \\
\text { burnout in nurses. Authentic leadership } \\
\text { can positively influence nurses' job } \\
\text { satisfaction and improve quality of } \\
\text { patient care }(\beta=0.17, \mathrm{P}<0.001) \text {. }\end{array}$ & --- & $78 \%$ \\
\hline $\begin{array}{l}\text { Laschinger HKS; } \\
\text { Fida } R^{(19)}\end{array}$ & $\begin{array}{l}\text { Job satisfaction } \\
\text { and quality of } \\
\text { patient care }\end{array}$ & Cross-sectional & $\begin{array}{l}\text { Authentic leadership had a positive effect } \\
\text { on structural empowerment }(\beta=.77) \text { and } \\
\text { on the professional practice environment } \\
(\beta=.69) \text {. Nurses' perceptions about } \\
\text { quality of care subsequently had a direct } \\
\text { positive effect on job satisfaction }(\beta=.21) \text {. }\end{array}$ & $92 \%$ & --- \\
\hline $\begin{array}{l}\text { Read EA, } \\
\text { Laschinger } \\
\text { HKS }^{(20)}\end{array}$ & $\begin{array}{l}\text { Social capital, } \\
\text { mental health } \\
\text { and job } \\
\text { satisfaction }\end{array}$ & Longitudinal & $\begin{array}{l}\text { By creating working environments with } \\
\text { structural empowerment }(\beta=0.50, p<0.05) \text {, } \\
\text { authentic leaders promote relational social } \\
\text { capital }(\beta=0.70, p<0.05 \text { ) among recent } \\
\text { graduates, leading to positive mental } \\
\text { health outcomes }(\beta=0.21, p<0.05) \text { and job } \\
\text { satisfaction }(\beta=0.50, p<0.05) \text {. }\end{array}$ & --- & $72 \%$ \\
\hline
\end{tabular}

\section{DISCUSSION}

Structural empowerment can be conceptualized as a set of systems and processes existing in the working environment that allows employees to perform their work in a meaningful way ${ }^{(20)}$.

Therefore, this set of systems and processes includes preparing leaders for the position, in order to seek an organizational leadership development approach that promotes the organization's corporate vision and values ${ }^{(21)}$.

By creating a structured empowerment environment, authentic leaders provide important relationship capital, leading to a healthy working environment with a high level of employee retention. Authentic leadership is seen by the followers as being characterized by an emphasis on management 
transparency, balanced processes, self-perception and high ethical standards. It is also concluded that authentic leadership leads to a feeling of empowerment and job satisfaction, with an increase in employee performance ${ }^{(17,20)}$.

The influence of the leadership exercised by nurses is extremely important in the commitment of the nursing team's workforce, where empowerment favors commitment to the organization, in addition to favoring quality of care and patient safety.

By providing the creation of a structured empowerment environment, leaders considered to be authentic significantly reduce emotional exhaustion and depersonalization in the groups studied; thus, effects are generated in professional retention and in the desire of others to join the structure in which authentic leadership is effectively exercised ${ }^{(16,20-23)}$.

The results suggest that structural empowerment, authentic leadership and an effectively professional nursing practice environment can improve interprofessional collaboration. They can create healthy working environments, which will favor the reduction of burnout, also impacting the intention of employees to leave the job, reducing turnover, in addition to enabling nurses to have high levels of satisfaction with their workplace ${ }^{(16-20)}$.

Motivation, empowerment and trust are important factors for the results mentioned to happen. Moreover, structural empowerment has as one of its assumptions developing policies that give employees access to the structures of the entity's body to which they provide services, bringing the real feeling that they are carrying out a significant work ${ }^{(22,24-26)}$.

Access to information, opportunities, resources and support, in addition to increasing autonomy and organizational commitment, foster the feeling that the work being developed is relevant and ends up promoting nurse retention ${ }^{(27)}$, avoiding the early loss of future talents or even talents already consolidated.

A structurally enabling environment is one that allows access to formal power; this comes from the visibility of internal work and its general importance for the organization's objectives. Informal power stems from developing relationships within the organization. Employees who have a high degree of formal and informal power have better access to organizational structures of information, support, resources and opportunities ${ }^{(28-29)}$.

Therefore, when thinking about nurse retention in health institutions, it is important to adopt contemporary leadership models, such as authentic leadership, to provide the structural empowerment so necessary for daily exercise. Nurses who have the power to do their work may be less frustrated and less likely to be intolerant to others, leading to greater incidences of aggression and intimidation in the workplace ${ }^{(27)}$.

The limitations of this study are centered on the fact that some research was not identified in the search period. However, knowledge is advanced by relating authentic leadership to structural empowerment, offering results that can support the work of nursing managers beyond Canada. This theme has been extensively investigated in this country by a group of specific researchers and new research will contribute to solidify the management practice of nurses in other settings.

The articles included show differences in both methods and outcomes; therefore, a meta-analysis was not performed, as its use in this situation could create hypothetical results.

\section{CONCLUSION}

Authentic leadership showed a positive relationship with structural empowerment, improving nurses' engagement in their work, their satisfaction with work, decreased burnout, in addition to increasing quality of care.

Leading nurses have an essential role in creating working conditions that favor the development of their team, and it is certain that their behavior directly affects their subordinates' experience with work. This shows that one can invest in authentic leadership development to improve structural empowerment through access to resources and information, training strategies, organizational changes, which will favor nurses' commitment, their satisfaction with work, favoring a better service and high quality of care provided. Furthermore, new studies can be developed considering other environments with different specificities to prove the effectiveness of this so promising leadership model.

\section{RESUMO}

Objetivo: Verificar a relação da liderança autêntica dos enfermeiros e o empoderamento estrutural. Método: Revisão sistemática realizada na Biblioteca Virtual em Saúde, no Portal de Periódicos da Coordenação de Aperfeiçoamento de Pessoal de Ensino Superior, Sistema Online de Busca e Análise de Literatura Médica, Scientific Electronic Library Online e Science Direct/Embase, consultadas até abril de 2019. Foram critérios de inclusão: estudos com enfermeiros, que evidenciassem a relação da liderança autêntica e o empoderamento estrutural, publicados entre 2012 e 2018 em português, inglês ou espanhol. Resultados: Foram incluídos cinco estudos, tendo outras variáveis além do empoderamento estrutural: satisfação no trabalho, burnout, bulling, saúde mental, performance, capital social, ambiente de trabalho, retenção dos enfermeiros e qualidade do cuidado. A liderança autêntica apresentou relação positiva com o empoderamento estrutural, melhorando o engajamento e a satisfação no trabalho, diminuindo o burnout e aumentando a qualidade da assistência. Conclusão: As instituições de saúde, além do Canadá, local onde estão os pesquisadores desta temática, podem investir na liderança autêntica para melhorar o empoderamento estrutural, proporcionando maior comprometimento dos enfermeiros, aumento da satisfação com o trabalho e qualidade da assistência prestada.

\section{DESCRITORES}

Enfermagem; Liderança; Ambiente de Trabalho; Poder Psicológico; Revisão.

\section{RESUMEN}

Objetivo: Verificar la relación entre el liderazgo auténtico del enfermero y el empoderamiento estructural. Método: Una revisión sistemática realizada en la Biblioteca Virtual en Salud, en el Portal de Periódicos de la Coordinación para el Perfeccionamiento del Personal de Educación Superior, Sistema en Línea de Búsqueda y Análisis de Literatura Médica, Scientific Electronic Library Online 
y Science Direct/Embase, consultado hasta abril de 2019 Los criterios de inclusión fueron: estudios con enfermeras, que mostraron la relación entre liderazgo auténtico y empoderamiento estructural, publicados entre 2012 y 2018 en portugués, inglés o español

Resultados: Se incluyeron cinco estudios, con variables distintas al empoderamiento estructural: satisfacción laboral, burnout, bullying, salud mental, desempeño, capital social, ambiente laboral, retención de enfermeras y calidad de la atención. El liderazgo auténtico mostró una relación positiva con el empoderamiento estructural, mejorando el compromiso y la satisfacción laboral, reduciendo el agotamiento y aumentando la calidad de la atención. Conclusión: Las instituciones de salud, además de Canadá, donde se encuentran los investigadores en este tema, pueden invertir en un liderazgo auténtico para mejorar el empoderamiento estructural, brindando un mayor compromiso por parte de los enfermeros, mayor satisfacción laboral y calidad de la atención brindada.

\section{DESCRIPTORES}

Enfermeria; Liderazgo; Ambiente de Trabajo; Poder Psicológico; Revisión.

\section{REFERENCES}

1. Silva DS, Bernardes A, Gabriel CS, Rocha FLR, Caldana G. A liderança do enfermeiro no contexto dos serviços de urgência e emergência. Rev Eletr Enf. 2014;16(1):211-9. doi: http://dx.doi.org/10.5216/ree.v16i1.19615

2. Besen F, Tecchio E, Fialho FAP. Liderança autêntica e a gestão do conhecimento. Gest Prod (São Carlos). 2017;24(1):2-14. doi: https:// doi.org/10.1590/0104-530x898-13

3. Balsanelli AP, Cunha ICKO. Liderança ideal e real dos enfermeiros de unidade de terapia intensiva em hospitais privados e públicos. Cogitare Enferm. 2016;21(1):1-7. doi: http://dx.doi.org/10.5380/ce.v21i4.42129

4. Silva VLS, Camelo SHH, Soares MI, Resck ZMR, Chaves LDP, Santos FC, et al. Leadership practices in hospital nursing: a self of manager nurses. Rev Esc Enferm USP. 2017;51:e03206. doi: http://doi.org/10.1590/s1980-220x2016099503206

5. Avolio BJ, Gardner WL. Authentic leadership development: getting to the root of positive forms of leadership. Leadersh Q. 2005;16(3):31538. doi: https://doi.org/10.1016/j.leaqua.2005.03.001

6. Esper AJF, Cunha CJCA. Liderança autêntica: uma revisão integrativa. Navus Rev Gestão Tecnol. 2015;5(2):60-72. doi: https://doi. org/10.22279/navus.2015.v5n2.p60-72.254

7. Carvalho AGF, Cunha ICKO, Balsanelli AP, Bernardes A. Liderança autêntica e perfil pessoal e profissional de enfermeiros. Acta Paul Enferm. 2016;29(6):618-25. doi: http://dx.doi.org/10.1590/1982-0194201600087

8. Bish M, Kenny A Nay R. Perceptions of structural empowerment: nurse leaders in rural health services. J Nurs Manage. 2014;22(1):29-37. doi: 10.1111 /jonm.12029

9. Laschinger HK, Finegan J, Shamian J, Wilk P. Impact of structural and psycological empowerment on job strain in nursing work settings: expanding Kanter's model. J Nurs Adm. 2001;31(5):260-72. doi: 10.1097/00005110-200105000-00006

10. Laschinger HKS, Finegan JE, Shamian J, Wilk P. A longitudinal analysis of the impacto f workplace emporwerment on work satisfaction. J Organiz Behav. 2004;25(4):527-45. doi: https://doi.org/10.1002/job.256

11. Higgins JPT, Green S, editors. Cochrane handbook for systematic reviews of interventions Version 5.1.0 [Internet]. London: The Cochrane Collaboration; 2011 [cited 2019 Mar 22]. Available from: www.handbook.cochrane.org

12. Galvão TF, Pereira MG. Revisões sistemáticas da literatura: passos para sua elaboração. Epidemiol Serv Saúde. 2014;23(1):183-4. doi: http://dx.doi.org/10.5123/S1679-49742014000100018

13. Center for Evidence Based Management. Critical appraisal checklist for cross-sectional study [Internet]. Leiden; 2011 [cited 2019 Mar 9]. Available from: https://cebma.org/resources-and-tools/what-is-critical-appraisal/

14. Healthcare Improvement Scotland. Metodology checklist 3: cohort studies [Internet]. London; 2014 [cited 2019 Mar 9]. Available from: https://www.sign.ac.uk/checklists-and-notes

15. Moher D, Liberati A, Tetzlaff J, Altman DG; PRISMA Group. Preferred reporting items for systematic reviews and meta-analyses: the PRISMA statement. PLoS Med. 2009;6(7):e1000097. doi: 10.1371/journal.pmed.1000097

16. Heather KS, Wong CA, Grau AL. Authentic leadership, empowerment and burnout: a comparison in new graduates and experienced nurses. J Nurs Manag. 2013;21(3):541-52. doi: 10.1111/j.1365-2834.2012.01375.x

17. Wong CA, Laschinger HK. Authentic leadership, performance, and job satisfaction: the mediating role of empowerment. J Adv Nurs. 2013;69(4):947-59. doi: 10.1111/j.1365-2648.2012.06089.x

18. Boamah AS, Read EA, Laschinger HKS. Factors influencing new graduate nurse burnout development, job satisfaction and patient care quality: a time-lagged study. J Adv Nurs. 2017;73(5):1182-95. doi: 10.1111/jan.13215

19. Laschinger HKS, Fida R. Linking nurses' perceptions of patient care quality to job satisfaction: the role of authentic leadership and empowering professional practice environments. J Nurs Adm. 2015;45(5):276-83. doi: 10.1097/NNA.0000000000000198

20. Read EA, Laschinger HK. The influence of authentic leadership and empowerment on nurses' relational social capital, mental health and job satisfaction over the first year of practice. J Adv Nurs. 2015;71(7):1611-23. doi: 10.1111/jan.12625

21. Leigh J. Modelling suggests authentic leadership from managers influences structural empowerment, job satisfaction and self-rated performance among nurses. Evid Based Nurs. 2014;17(2):55-6. doi: 10.1136/eb-2013-101424

22. Laschinger HKS, Finegan J, Wilk P. The impact of unit leadership and empowerment on nurses' organizational commitment. J Nurs Adm. 2009;39(5):228-35. doi: 10.1097/NNA.0b013e3181a23d2b

23. Richardson A, Storr J. Patient safety: a literative review on the impact of nursing empowerment, leadership and collaboration. Int Nurs Rev. 2010;57(1):12-21. doi: 10.1111/j.1466-7657.2009.00757.x

24. Regan S, Laschinger HK, Wong CA. The influence of empowerment, authentic leadership, and professional practice environments on nurses' perceived interprofessional collaboration. J Nurs Manag. 2016; 24(1):E54-61. doi: 10.1111/jonm.12288 
25. Bamford $\mathrm{M}$, Wong $\mathrm{CA}$, Laschinger $\mathrm{H}$. The influence of authentic leadership and areas of worklife on work engagement of registered nurses. J Nurs Manag. 2013;24(3):529-40. doi: 10.1111/j.1365-2834.2012.01399.x

26. Laschinger HKS, Wong CA, Grau AL. The influence of authentic leadership on newly graduated nurses' experiences of workplace bullying, burnout and retention outcomes: a cross-sectional study. Int J Nurs Stud. 2012;49(10):1266-76. doi: 10.1016/j.ijnurstu.2012.05.012

27. Papathanasiou IV, Fradelos EC, Kleisiaris CF, Tsaras K, Kalota MA, Kourkouta L. Motivation, leadership, empowerment and confidence: their relation with nurses' burnout. Mater Sociomed. 2014;26(6):405-10. doi: 10.5455/msm.2014.26.405-410

28. Read E, Laschinger HK. correlates of new graduate nurses' experiences of workplace mistreatment. J Nurs Adm. 2013;43(4):221-8. doi: 10.1097/NNA.0b013e3182895a90

29. Cziraki K, Laschinger $\mathrm{H}$. Leader empowering behaviours and work engagement: the mediating role of structural empowerment. Nurs Leadersh (Tor Ont). 2015;28(3):10-22. 